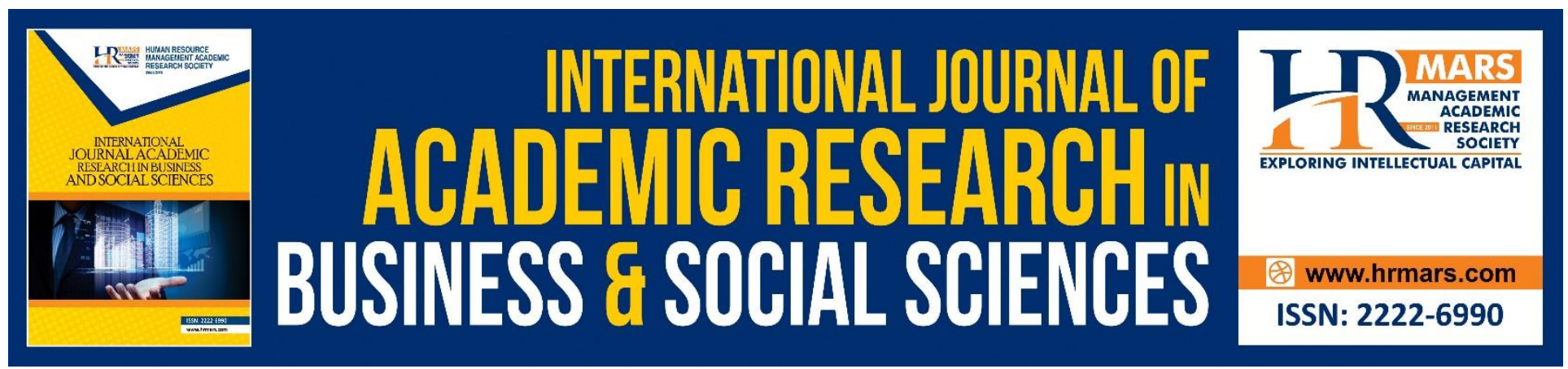

\title{
Relationship between Entrepreneurial Leadership and School Effectiveness among Secondary Schools
}

\section{Zaidatol Akmaliah Lope Pihie, Abbas Sani Dahiru, Ramli Basri, Siti Aishah Hassan}

To Link this Article: http://dx.doi.org/10.6007/IJARBSS/v8-i12/5010

DOI: $10.6007 /$ IJARBSS/v8-i12/5010

Received: 27 Oct 2018, Revised: 22 Nov 2018, Accepted: 16 Dec 2018

Published Online: 19 Dec 2018

In-Text Citation: (Pihie, Dahiru, Basri, \& Hassan, 2018)

To Cite this Article: Pihie, Z. A. L., Dahiru, A. S., Basri, R., \& Hassan, S. A. (2018). Relationship between Entrepreneurial Leadership and School Effectiveness among Secondary Schools. International Journal of Academic Research in Business and Social Sciences, 8(12), 258-274.

\section{Copyright: (C) 2018 The Author(s)}

Published by Human Resource Management Academic Research Society (www.hrmars.com)

This article is published under the Creative Commons Attribution (CC BY 4.0) license. Anyone may reproduce, distribute, translate and create derivative works of this article (for both commercial and non-commercial purposes), subject to full attribution to the original publication and authors. The full terms of this license may be seen

at: http://creativecommons.org/licences/by/4.0/legalcode

\section{Vol. 8, No. 12, 2018, Pg. 258 - 274}

Full Terms \& Conditions of access and use can be found at http://hrmars.com/index.php/pages/detail/publication-ethics 


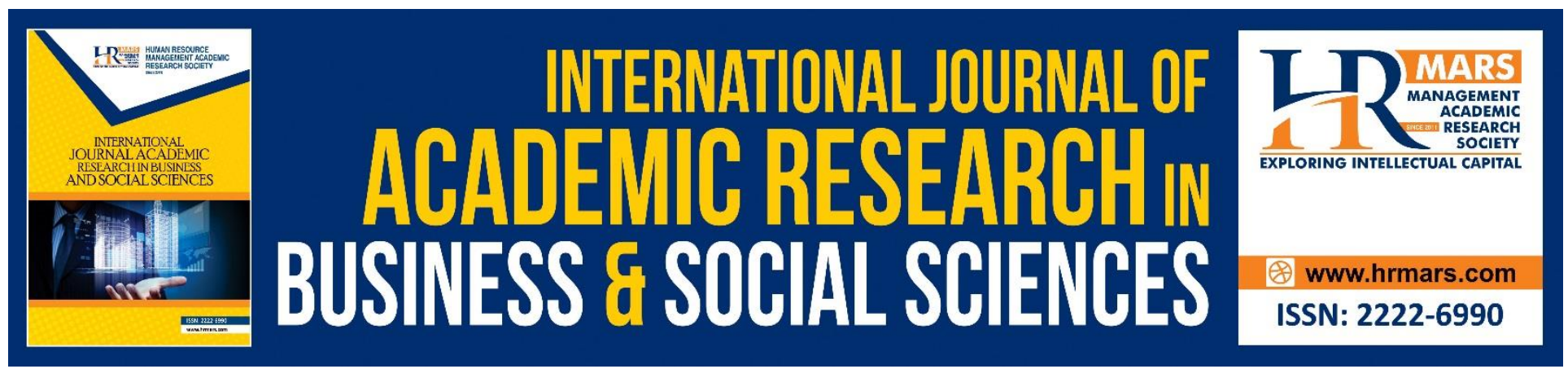

\title{
Relationship between Entrepreneurial Leadership and School Effectiveness among Secondary Schools
}

\section{Zaidatol Akmaliah Lope Pihie, Abbas Sani Dahiru, Ramli Basri, Siti Aishah Hassan}

Faculty of Educational Studies, Universiti Putra Malaysia, 43400 UPM Serdang, Selangor Darul

Ehsan, Malaysia

\begin{abstract}
There is a general consensus among stakeholders in education that a strong positive educational leadership is a determining factor of school effectiveness. However, many questions were raised as regards to the applicability of entrepreneurial leadership in the context of education. The main purpose of this study is to determine the relationship between entrepreneurial leadership and school effectiveness, and also to identify the dimension of entrepreneurial leadership that contributes more to school effectiveness. The research adopted a survey design and a total sample of 358 secondary school teachers in Zamfara State, Nigeria were selected through simple random sampling from a total population of 4996 as a sample for the study, using Cochran's sample size determination formula. Data were collected through survey method and were analyzed using both descriptive and inferential (Pearson correlation and multiple regression) statistical analyses. The findings of the study indicated the existence of significant and strong relationship between entrepreneurial leadership practice and school effectiveness $(p<0.05)$, also accelerator behavior appeared to be the highest predictor of school effectiveness among secondary schools in Zamfara State $(\beta=.335, t=6.265, p<.01)$. This implies that entrepreneurial leadership dimension (accelerator behavior) facilitates school effectiveness of secondary school leaders in the study area and efforts should be made towards increasing its level through motivating the teachers.
\end{abstract}

Keywords: Entrepreneurial Leadership, School Effectiveness, Secondary Schools, School Principals

\section{Introduction}

One of the main purposes of ensuring schools has leaders that are creative, innovative and flexible, is to facilitate positive change in teaching and learning process, which in the long run can be a yardstick of achieving both school objective and the required societal change (Woods, 2004). However, many scholars observed that school effectiveness is a wide scope that is concerned with the culture and organizational structure of a school, at the same time articulating the manners for the improvement of policies, plans, and practices for the realization of general school objectives and 
INTERNATIONAL JOURNAL OF ACADEMIC RESEARCH IN BUSINESS AND SOCIAL SCIENCES Vol. 8, No. 12, Dec, 2018, E-ISSN: 2222-6990 @ 2018 HRMARS

teacher effectiveness in classroom and school level in general (Hargreaves, 2001). An effective school is characterized by completing student achievement across all the subgroups in the school. Similarly, Lezotte and Snyder (2010) described an effective school as the one that is established on the basis of high expectation for success, strong educational leadership, quality teaching, safe and orderly school environment and frequent monitoring of students' progress.

Moreover, Ofoegbu, Clark, \& Osagie (2013) opined that, there is a general consensus among stakeholders in education that a strong positive educational leadership is a determining factor of school effectiveness. This is due to the fact that effective school principals (school leaders) have the capability to facilitate school effectiveness by understanding the technical side of education, and are aware of the conditions and time to adjust their leadership practices (Waters, Marzano, \& McNulty, 2003). However, it is generally proven that, the success of a school is tied to a successful leadership provided by the school principals (Leithwood \& Jantzi, 2006). Therefore, a strong and vibrant leadership is an indispensable factor in guaranteeing an effective school (Ofoegbu, Clark, \& Osagie, 2013). The present day educational leadership in schools is faced with new and unforeseen challenges that appear to be defective in day to day management of schools (Walker \& Carr-Stewart, 2006). Consequently, this calls for the need by the school leaders to embrace and incorporate entrepreneurial leadership practice, this would assist in the realization of the goals stated for the schools through the application of innovativeness, risk taking and creativity of which other leadership styles are lacking. Entrepreneurial leadership simply refers to a specific leadership style that empowers leaders to confront administrative issues related to their responsibilities and roles in their respective organizations (Dimovski, Penger, Peterlin, \& Uhan, 2013). Accordingly, it assists leaders in guiding people to attain the organizational goals and addressing hitches in different phases of organizational evolution and on the other hand, the encounters and predicaments found in the organizational environment (Bagheri, Pihie, \& Krauss, 2013).

Furthermore, it was strongly observed that in Nigeria, educational leadership is considered as an essential tool for the realization of educational development. The goals of education in Nigeria are contained in the country's national document on education (Adeyemi, 2010). The Nigerian educational administration is faced with several challenges, such as poor resource mobilization, underutilization of the available resources, dynamic leadership styles that suit changes occurring as result of time, space and materials, cultural diversity, dwindling quality that are aimed at regulating education with the aim of making schools more effective (Olubebe, 2015). The need of an effective school leaders in the realization of the goals and objectives of education in Nigeria, as well as addressing numerous hitches and challenges in school organization has necessitated the use of entrepreneurial leadership paradigm in our school system, because it takes care of high agitations for the improvement of secondary school education and also has component of addressing the shortage of school resources that guarantee school effectiveness (Pihie, Asimiran, \& Bagheri, 2014).

Furthermore, there are inadequate researches on the relationship between entrepreneurial leadership practice and school effectiveness in Nigeria and the few existing on entrepreneurial leadership practice focus more on other areas such as profit making ventures and not in educational 
settings (Olasode, 2015). In response to the aforementioned inadequacies, this paper analyzed the teacher's perception on the relationship between entrepreneurial leadership practice and school effectiveness among secondary schools in Zamfara State, Nigeria and also identify the contribution of entrepreneurial leadership dimensions to overall school effectiveness. The findings of this research may provide sufficient empirical evidence as regards to the entrepreneurial leadership practice and school effectiveness and also serve as a source of reference for future researchers.

\section{Literature Review}

\section{School Effectiveness Concept and Dimensions}

School effectiveness is a very wider concept that received different definitions from different perceptions. Going by the existing literature, Majority of the past researchers on school effectiveness defined the concept from the view point of overall academic achievement (Dobbie \& Fryer Jr, 2013). According to Lumpe (2007) the indices to be used in assessing an effective school is a condition whereby all the students are educated regardless of their socio-economic and family affiliations. Accordingly, schools are adjudged to be effective if the achievements of the school is characterized by high quality and quantity of goal attainment (Mortimore, Sammons, \& Thomas, 1994). Justifications for categorizing a school as effective or otherwise are reliant on so many factors in the school which are very crucial to the accomplishment of a wide-range of school goals and objectives (Abd-Elmotaleb \& Saha, 2013). This current study conceptualized school effectiveness using the model of Lezzote and Snyder (2010) that defined school effectiveness as the combinations factors that they referred to as "Correlates". The factors are: strong instructional leadership, clear and focused mission, safe and orderly school environment, high expectations for success, frequent monitoring of student progress, opportunity to learn on time/ task and lastly positive school/ home relations (Lezotte \& Snyder, 2010). The model was adopted to explain school effectiveness due to the fact that it discussed school effectiveness extensively by explaining the principal's organizational indicators of school effectiveness (Talebloo, 2015). The dimensions of school effectiveness based on the definition of Lezotte and Snyder (2010) are discussed below:

\section{A Clear School Mission}

This refers to the ability of a school to have a visible and articulated school mission which would provide the teachers with an opportunity to discuss their understanding and make them committed to the attainment of instructional objectives and the overall objectives of the school (Ghani, Siraj, Radzi, \& Elham, 2011). Teachers have a critical role to play in partnering with the school leadership to initiate and achieve the school vision (Kirk \& Jones, 2004).

\section{High Expectations for Success}

This climate exist's when the teachers are optimistic that the students have the potentials to master the basics of the school curriculum, and at the same time, teachers also have self-confidence that they also possess the talents of putting the students through to mastery (Lezotte, 2001). Moreover, under this kind of situation, it is assumed that each student possess a special skill to offer to society (Domitrovich \& Greenberg, 2000). 


\section{Instructional Leadership}

This is a situation where the principal serves as an instructional leader, and also keeps both the teachers and other stakeholders aware of the missions and visions of the school. This leads to the building of a common sense of determination and promotes a culture of mutual fundamental beliefs among the teachers and other school members (Lezotte, 2001).

\section{Opportunity to Learn and Student Time on Task}

This refers to the provision of a quality and sufficient time in teaching the subject matter for effective teaching and learning process. This is vital in addressing challenges of emerging curricular demands with insufficient instructional time. It also includes the design of an interdisciplinary curriculum to impart some basic skills within a very short period of time, making assessments regarding what is of utmost importance (Ghani, 2011).

\section{A Safe and Orderly Environment}

This is the school's ability to create and maintain a well-organized atmosphere that is full of discipline devoid of unwanted behaviors and free from risks of physical damage (Lezotte, 2001). Lezotte and Jacoby (1991) further stated that a safe school environment is characterized by a supportive team learning, regard for individual differences and regard for independent beliefs.

\section{Positive Home-School Relations}

The existence of a synergy between school and home is paramount in the achievement of an effective school. This is situation whereby parents appreciate and promote the mission of the school and they play crucial parts in the realization of school goals (Lezotte, 2001). Thus, it is the responsibility of the schools to do whatsoever they can within their own capacity with a view to involve and other members of the society in supporting the education of their children (Borman, Hewes, Overman, \& Brown, 2003).

\section{Frequent Monitoring of Student Progress}

In the effective schools, the progress of the students is given a special priority by regularly assessing the progress of the learners, and the results are utilized in improving the performance and conduct of the students and to improve the curriculum in general (Lezotte, 2001).

Furthermore, in recent times scholars such as Zins (2004) and Barath (2015) have identified learning organization as an important feature of effective schools, it is the activity of teachers, the organization of learning and the quality of teaching that has the largest effect on the effectiveness of schools (Mourshed, 2010). The concept learning organization had been conceptualized in various ways by researchers. These include the learning to learn view which is focused on problem solving (Handy, 1991; Senge, 1990; Swieringe and Wierdsma, 1994); the knowledge perception focusing on the generation, transmission and assimilation of knowledge (Dixon, 1994; Garvin, 1993) and lastly the change perspective which is geared towards refining and transforming the organization in order to adjust to the dynamic environment (Janet, 2004). Researchers have attempted to identify a set of 
INTERNATIONAL JOURNAL OF ACADEMIC RESEARCH IN BUSINESS AND SOCIAL SCIENCES Vol. 8, No. 12, Dec, 2018, E-ISSN: 2222-6990 C 2018 HRMARS

characteristics typical of a learning organization, According to Senge et al (2000) there exist five features that a school as a learning organization should uphold for the attainment of overall effectiveness. The features are: developing personal mastery, developing mental mode, developing a shared vision, developing team learning, and developing the system of thinking in schools.

The table below has summarized the definitions and dimensions of effective schools based on different authors.

Table 1: Some Dimensions of School Effectiveness

\begin{tabular}{ll}
\hline Author/s & Dimensions \\
\hline Lezotte \& Snyder (2011). & Strong instructional leadership, clear and focused mission, \\
& safe and orderly environment, high expectations for success, \\
frequent monitoring of student progress, opportunity to & learn and time on task and positive home school relations.
\end{tabular}

Marzano (2005)

A safe and orderly environment that supports cooperation and collaboration, an instructional framework that develops and maintains effective instruction in every classroom, a guaranteed and viable curriculum focused on enhancing student learning, a standards-referenced system of reporting student progress and a competency-based system that ensures student mastery of content.

Edmonds (1979)

Strong administrative leadership, a climate of expectation in which no child is permitted to fall below minimum levels of achievement, the school's atmosphere is orderly without being rigid, quiet without being oppressive, and conducive to instruction, school resources are diverted from other business to further the fundamental objectives, pupil progress is frequently monitored using various types of assessments and pupil acquisition of basic skills takes precedence.

Senge et al. (2000)

Developing personal mastery, developing mental mode, developing a shared vision, developing team learning, and developing the system of thinking in schools.

Based on the examination of diverse definitions of effective schools by different authors, it is clearly evident that school effectiveness is a very much wider concept. There exists a conceptual hierarchy of bivalence where effective and ineffective schools are measured by characteristics (Ball, 1997). 
Furthermore, Sammons (1994) argued that definitions on school effectiveness are being determined by number elements that include sample of schools examined and choice of outcome measured (Saleem, 2012). A critical examination of the various definitions of an effective school have shown that almost all the researchers have focused on some specific aspects of school effectiveness depending on their areas of concern, not minding the holistic approach which encompasses the entire purview of effective schools, to address these shortcomings, the seven correlates of school effectiveness by Lezzote and Snyder (20110 have basically focused on general factors that might bring about effective school regardless of operational differences. Moreover, a careful study of the Lezzote and Snyder (2010) indicates that it has succeeded in accommodating all the standpoints of the extant dimensions of other models, as well as taking in to cognizance the role of clear and focused mission which is very significant in view of fast changing society and the necessity for positive home school relationship that has not been clearly recognized by the earlier researchers.

\section{Entrepreneurial Leadership Concept and Dimensions}

There are serious debates and opinions related to concept of entrepreneurial leadership definition, description and explanation, but the central issue is that all the definitions agreed that it is about bringing about changes and innovations in the leadership of an organization (Roomi \& Harrison, 2011). It is defined as inculcating and communicating the vision to make individuals identify, expand and take utilize opportunity in order to achieve competitive value (Roomi \& Harrison, 2011). Putting in to practice entrepreneurial skills by leaders and leadership values by entrepreneurs have a central goal which is addressing the challenges dilemmas of existing organizational settings which will in turn lead to improving the effectiveness of the leaders (Cogliser \& Brigham, 2004). Typical entrepreneurial leaders are driven their interest to mirror how to establish social, environmental set up in an organization and also set a prospect for effectiveness concurrently. Entrepreneurial leaders are not discouraged by organizational challenges such as limited financial and material resources. Rather, they devise a means of providing way out to organizational problems (Greenberg, McKone-Sweet, \& Wilson).

As a result of reoccurring challenges encountered by leaders in the process of transforming their organizations from a transactional to entrepreneurial organizations Gupta, MacMillan, and Surie (2004) formulated a theory to explain entrepreneurial leadership. The theory advances two key encounters confronting leaders with an entrepreneurial mindset: "Scenario enactment" and "Cast enactment". Scenario enactment dwelled much on the tasks of entrepreneurial leaders in envisaging the vision and building a scenario of innovative prospects. In order to address this challenge, Gupta (2004) identified the need for leaders to adopt proactiveness and predicate impending opportunities and challenges and also address different entrepreneurial opportunities that may emerge. While on the other hand, cast enactment, refers to the challenges faced by I leaders with entrepreneurial mindset in their bid to process and persuade a group of organization members that are capable and keen to achieve organizational goals.

However, this paper adopted the model of entrepreneurial leadership by Thornberry (2006) to explain the dimensions of entrepreneurial leadership. The model is considered to be one of the best 
models to explain entrepreneurial leadership due to the fact that it was developed by integrating three different leadership styles (transformational, transactional and charismatic). Also, the model discussed entrepreneurial leadership practice at both personal and organizational platforms, the model is referred to as a "multi-dimensional approach" due to the fact that it emanated as a result of the combination of three different leadership styles. Thornberry (2006) viewed entrepreneurial leadership as having five major dimensions that include:

\section{General Entrepreneurial Leadership Behavior}

This refers to the ability of the leader to internalize and apply an entrepreneurial attitude in leadership activities with his subordinates and create a positive and supportive atmosphere for the staff to be innovative and apply risks taking in the conduct of their duties and continue in the face of hitches and rapidly modify the policies that may not lead to success (Thornberry, 2006).

\section{Miner Behavior}

Miner behavior allows the leader to face inward and look for means to identify and unearth the hidden opportunities that often lies in the company's own operations and developments. Motivated miners enjoy doing much with less to exhibit their talents. Miners generally need more organizational approval and have less individual control due to the fact that they embark on inner activities that requires them to go beyond the organizational rules (Thornberry, 2006). Principal's miner behavior is determined by his capacity to study the work flow and performance of teachers and on the other hand empowering them to resolve challenges that the school may be faced with at their own capacity (Pihie et al., 2014).

\section{Explorer Behavior}

This is the leader's ability to identify discovering new opportunities that will lead to the accomplishment of the organizational goals. In a school setting, is the principal's ability to stimulate and encourage teachers to develop new and innovative ideas that are aimed at developing the process of teaching and learning (Pihie et al., 2014).

\section{Accelerator Behavior}

Accelerator behavior denotes to the leaders' zeal and passion to stimulate his subordinates to engage in creative thinking. Accelerator behavior encloses inspiring subordinates for creative thinking, inspiring them to develop their performance at work by applying innovative approaches and producing a supportive atmosphere for them to try new innovative approaches (Pihie et al, 2014).

\section{Integrator Behavior}

This accounts for leader's ability to not only communicate but also involve his subordinates in the formulation of organization's vision and also motivate them to engage in entrepreneurial thinking as well as providing them with required resources for innovative ideas. At the school level, integrator of the principal encompasses spreading of information on new educational trends, encouraging and supporting new educational policies and keeping the school on track in its mission (Pihie, et al, 2014). 
INTERNATIONAL JOURNAL OF ACADEMIC RESEARCH IN BUSINESS AND SOCIAL SCIENCES

Vol. 8, No. 12, Dec, 2018, E-ISSN: 2222-6990 @ 2018 HRMARS

\section{Entrepreneurial Leadership and School Effectiveness}

There exists a common belief among the educators that, strong educational leadership is a predicting factor that determines the level of school effectiveness. It is largely believed that, no school can flourish in the absence of a robust principals' leadership. Past researches strongly indicated that, principals' leadership influences the overall effectiveness of a school (Leithwood \& Jantzi, 2006). Strong leadership is essential in the realization of school effectiveness; this is due to fact that leadership elements serve as important catalysts to form an effective school (Shannon \& Bylsma, 2007).

Entrepreneurial leadership being a developing concept in the field of education and previous literatures have revealed that there exist only few researches on entrepreneurial leadership in relation to educational context (Berglund \& Holmgren, 2006). The influence of entrepreneurial leadership on the effectiveness of school system had been diagnosed from two different perspectives by researchers. However, the two were considered to be ways of rational thinking and a way of life but not just for the purpose of establishing new business (Pihie et al., 2014). This substantiates the fact that elements of entrepreneurial leadership can be adopted in the course of improving school leadership through influencing the conduct of school members (Berglund \& Holmgren, 2006). Thus, this justifies the need for school heads (principals) to internalize and practice the skills of entrepreneurial leadership for the realization of school effectiveness as well as the enabling of school innovation practice (Hamzah, Yusof, \& Abdullah, 2009). Based on the above discussions, it is evident that entrepreneurial leadership practice has a place in all facets of education including school leadership by a way of influencing the leaders' behaviour and task accomplishment (Berglund \& Holmgren, 2006; Eyal \& Kark, 2004).

The conceptual framework of the research is presented in Figure 1

\begin{tabular}{|c|c|}
\hline $\begin{array}{l}\text { Entrepreneurial Leadership } \\
\text { - General } \\
\text { Entrepreneurial } \\
\text { Behaviour } \\
\text { - Miner Behaviour } \\
\text { - Explorer Behaviour } \\
\text { - Accelerator Behaviour } \\
\text { - Integrator Behaviour }\end{array}$ & $\begin{array}{l}\text { School Effectiveness } \\
\text { - } \text { Instructional Leadership } \\
\text { - } \text { Clear Mission } \\
\text { - } \text { Safe \& Orderly } \\
\text { Environment } \\
\text { - } \text { Expectation for Success } \\
\text { - } \quad \text { Frequent Monitoring of } \\
\text { - } \text { Oprogress } \\
\text { - } \text { Time } \\
\text { Positive Home School } \\
\text { Relations }\end{array}$ \\
\hline
\end{tabular}

Figure 1 Research Conceptual Framework 
Thornberry (2006) model, consisting of 5 dimensions, was developed to explain entrepreneurial leadership at both individual and managerial stages which would consequently lead to effectiveness of schools. The model was applied to measure entrepreneurial leadership behaviour among principals of secondary schools in Malaysia and it proved to be effective (Pihie and Bagheri, 2014). Thornberry (2006) focused on both personal and interactive skills required by leaders to provide clear and focused missions among their teachers, particularly frequent monitoring of progress, ensuring successful achievement of goals by offering timely learning opportunity in achieving success, through effective instructional leadership, which school effectiveness is all about. In addition, the model highlighted challenges faced by entrepreneurial leaders at different phases of entrepreneurial leadership. According to the model, for entrepreneurial leaders to solve organizational problems there by lead to an effective organization, they need to internalise and apply entrepreneurial leadership behaviours that include; general entrepreneurial leader, explorer, miner, integrator and accelerator behaviours. Thus, the application of the model by school principals will lead to the actualization of an effective school in Zamfara State, Nigeria which is part of the basic philosophies of the National policy on Education (FGN, 2004).

A critical review of the reviewed literature in terms of several definitions, models and relationship between entrepreneurial leadership and school effectiveness it appeared that there is a consensus among researchers that that the leadership style occupies a vital position in the progress and success of organizations (Chen, 2007; Yang, 2008). Furthermore, bulk of the literatures on entrepreneurial leadership practice revised in this research shown that most of the literatures on entrepreneurial leadership dwelled much on the relevance of the leadership practice in the profit making organizations neglecting other non-profit making organizations such as the school context.

\section{Materials and Methods}

\section{Participants and Sampling}

The study population comprises of all the teachers in the public secondary schools in Zamfara state. According to the records obtained from the Zamfara State Ministry of Education, there are 4996 teachers serving in 191 secondary schools dispersed across 14 local government areas of the state. Cochran's formula (2007) was employed to calculate the sample size. As a result, the total recommended sample size for this study is 357 . Still, an additional $10 \%$ was added to the minimum sample to take care of non-response from the teachers during the data collection process (Rea et al., 2012) and (DeVellis, 2013). Therefore, the total sample distributed is 393 to teachers all over the state. Then the participants were chosen through a simple random sampling considering the fact that all the teachers have equal chance to participate in the research. Out of 358 teachers that participated in the research, $211(58 \%)$ are male while $147(41.1 \%)$ are females. Also, $41(11.15 \%)$ of the respondents were holders of master degrees, 204 (57\%) were holders of Bachelor of education degrees and 113 (31.6\%) were having Nigerian Certificate in Education. Furthermore, the researcher obtained permission from the State Ministry of Education. Thereafter, the researcher went round the sampled schools and collected the data. 


\section{Instrumentation}

Two instruments were adopted to measure the two variables of the research. In order to measure school effectiveness, Lezzote and Snyder (2011) instrument was adopted. The instrument is a five Likert type scale instrument ranging from (strongly disagree, disagree, undecided, agree and strongly agree) with 38 items. It was developed from Lezzote and Snyder's (2011) model of seven correlates of school effectiveness. The instrument covers seven dimensions (seven correlates of school effectiveness) that include: Instructional leadership, clear and focused mission, safe and orderly environment, high expectations, frequent monitoring of students' progress, opportunity to learn/time on task and home-school relations. The instrument is having a Cronbach's alpha value of .949 and composite reliability of .913 which shows that the instrument is reliable and valid. The instrument was adopted in this research for the reason that majority of researchers on school effectiveness have identified the instrument as more acceptable and of international standard (Marzano, 2000; Saleem, 2012). To measure entrepreneurial leadership practice, entrepreneurial leadership questionnaire (ELQ) developed by Thornberry (2006) was adopted. It was modified to a five Likert type scale consisting of 50 items measuring five dimensions of entrepreneurial leadership including general entrepreneurial leader behavior (GELB), explorer behavior (EXPB), miner behavior (MINB), accelerator behavior (ACCB) and integrator behavior (INTB). However, as a result of the fact that the instrument originated from the business arena some words in the questionnaire were modified in order to make it suitable to school situations. The instrument recorded a Cronbach's alpha value of .963 and composite reliability of .896 which shows that the instrument reliable and valid. Furthermore, the instruments were subjected to both content and face validity by experts in Malaysia and Nigeria after which their observations and comments were taken in to consideration.

\section{Data Analysis and Findings}

The data were analyzed using descriptive statistics in order to present the demographic characteristics of the respondents and inferential analysis (Pearson moment correlation, and standard multiple regression) statistics were used to determine the relationship between variables under study.

\section{Relationship between Entrepreneurial Leadership and School Effectiveness}

Pearson Product-Moment Correlation Coefficient $(r)$ which measures the strength of the association that exists between two quantitative variables was conducted to examine the relationships between the independent variable (entrepreneurial leadership practice) and the dependent variable (school effectiveness). The data were checked to ensure no violation of the basic assumptions of normality, linearity and homoscedasticity. The strength of relationships was examined using Cohen (1988) and Tian and Wilding (2008) rules as indicated by Tseng (2010). The correlation matrix of the above mentioned variables and the interpretations are presented in Table 2. 
INTERNATIONAL JOURNAL OF ACADEMIC RESEARCH IN BUSINESS AND SOCIAL SCIENCES Vol. 8, No. 12, Dec, 2018, E-ISSN: 2222-6990 @ 2018 HRMARS

Table 2: Correlation Matrix between School Effectiveness and Entrepreneurial Leadership

\begin{tabular}{lll}
\hline \hline Variable & $\mathbf{Y}$ & $\mathbf{X}_{\mathbf{1}}$ \\
\hline \hline $\mathbf{Y}$ (School Effectiveness) & 1 & \\
$\mathbf{X}_{\mathbf{1}}$ (Entrepreneurial Leadership) & $.683^{* *}$ & 1
\end{tabular}

**. Correlation is significant at the 0.05 level (2-tailed).

The Pearson correlation analysis of Table 1 revealed that there is a high and significant relationship between school effectiveness and entrepreneurial leadership practice among secondary schools in Zamfara State. $(r=.683, p<.05)$. This means that the more the principals practice entrepreneurial leadership, the higher the school would be effective in terms of Instructional leadership, clear and focused mission, positive home/school relations and high expectation for student's success.

\section{Contribution of Entrepreneurial Leadership Dimensions to Overall School Effectiveness}

In order to test for the contribution of dimensions of entrepreneurial leadership to overall school effectiveness in the regression model, standard multiple regression was employed. The preliminary assumptions testing for normality, linearity, multicollinearity and homoscedasticity proved non violation of the basic assumptions. Thus, summary ANOVA result indicated that, the regression model is significant $\left(F_{(5,352)}=58.785 ; p=.000\right)$. Moreover, the analysis showed that about $45 \%$ of variance in school effectiveness was explained by the entrepreneurial leadership dimensions entered in to the regression model.

Table 3: Multiple Regression Analysis among Variables of the Study

\begin{tabular}{llllll}
\hline \hline Variables & B & S.E & $\boldsymbol{\beta}$ & t & P \\
\hline (Constant) & 49.983 & 5.218 & & 9.578 & .000 \\
General Entrepreneurial Behavior & 4.226 & .758 & .282 & 5.574 & .000 \\
Explorer Behavior & 1.393 & .728 & .086 & 1.913 & 0.56 \\
Miner Behavior & 1.382 & .452 & .134 & 3.054 & 0.002 \\
Accelerator Behavior & 4.453 & .711 & .335 & 6.265 & 0.00 \\
Integrator Behavior & .386 & .656 & .028 & .529 & 0.557 \\
$\mathrm{R}^{2}=.455 ;$ Adjusted $\mathrm{R}^{2}=.447 ; \mathrm{F}_{(5,352)}=58.785 ; p<.05$ & & & \\
\hline \hline
\end{tabular}

Note: $B=$ Unstandardized Coefficients; S.E= Standard Error; $\beta=$ Standardized Coefficients.

The regression analysis in Table 3 shows a significant relationship between general entrepreneurial leader behavior and overall school effectiveness $(\beta=.282, t=5.574, p<.01)$. This confirms that general entrepreneurial leader behavior is a significant predictor of school effectiveness. From the findings of the results as shown in Table 3, there is no significant relationship between explorer behavior and overall school effectiveness $(\beta=.086, t=1.913, p>.01)$. This clearly indicates that explorer behavior is not a significant predictor of school effectiveness. Accordingly, Table 2 also indicated that there is 
INTERNATIONAL JOURNAL OF ACADEMIC RESEARCH IN BUSINESS AND SOCIAL SCIENCES

Vol. 8, No. 12, Dec, 2018, E-ISSN: 2222-6990 @ 2018 HRMARS

a significant relationship between miner behavior and overall school effectiveness $(\beta=.134, t=3.054$, $\mathrm{p}=0.02$ ). This shows that miner behavior is a significant predictor of school effectiveness. Moreover, the results in Table 2 have also shown that there is a significant relationship between accelerator behavior and overall school effectiveness $(\beta=.335, t=6.265, p<.01)$. This depicts that accelerator behavior is a significant predictor of school effectiveness. Lastly, the results in Table 2 indicated that, there is no significant relationship between integrator behavior and overall school effectiveness ( $\beta=$ $.028, t=.529, p>.01)$. This indicates that integrator behavior is not a significant predictor of school effectiveness. Therefore, it can be established that among the dimensions of entrepreneurial leadership, accelerator behavior contributes more to the overall school effectiveness.

\section{Discussions}

The findings of this study found a significant relationship between entrepreneurial leadership practice and school effectiveness. In other words, the higher the level of entrepreneurial leadership practiced by school principals, the more school would be effective. This means that the ability of the school principal to identify different ways to improve and develop the school, supports the suggestions of teachers for improving the school and engage broad network of experts both within and outside the school that are willing to help if the need arise will lead to a strong instructional focus, a high level of discipline in schools and above all an effective school system. This proves the fact that elements of entrepreneurial leadership can be adopted in the course of improving school leadership through influencing the conduct of school members (Berglund \& Holmgren, 2006). In accordance with the observation made by Bergland and Holman it is vividly clear that the ability of the school principal to explore and harness available human and material resources to achieve effectiveness became imperative, especially where teachers received encouragement to outwit and out-manoeuvre the schools bureaucracy and passionately find innovative approaches to develop the school. The above assertion, is in agreement with the findings of Pihie and Asimiran (2014) who conducted their research to identify relationship between principal's entrepreneurial leadership practice and school innovativeness in Malaysia, the outcome of their research established significant relationship between teachers' perceptions of the importance of the school principals' entrepreneurial leadership practices and school innovativeness. Accordingly, from their findings the more often school principals adopt entrepreneurial leadership approaches in leading their schools, the higher the schools will be more innovative (effective).

Similarly, the findings of this were in harmony with Olasode (2015) who found that entrepreneurial leadership is strongly related to school effectiveness among secondary schools in Ondo State, Nigeria. According to his findings, application of an entrepreneurial leadership culture by school leaders leads to a creative, innovative and productive school system. Indeed one of the remissions to effectiveness earlier observe in schools are under utilization of available network of people throughout that are willing to extensively contribute to the effectiveness of school if given the opportunity. This further confirms the critical role of principal's entrepreneurial skills towards the attainment of a highly innovative and effective school setting (Eyal \& Kark, 2004). In essence, the findings of this study established that the ability of the school principal to promote an environment where risk taking is encouraged and develop a passion in looking for new ways to develop the school will certainly lead 
to the attainment of a strong and positive instructional leadership, clear and focused mission and safe and orderly school environment which are of paramount importance towards the realization of an effective school system.

On the other hand, the findings of this study established that accelerator behavior has high predictive ability on school effectiveness. This clearly depicts that accelerator behavior practices such as; the school principal's ability to create a climate that encourages continuous improvement, create an environment where school teachers feel free to try new things, motivate teachers to think about how to do their work in new and interesting ways and supports teachers suggestions for improving the school all contributes more to the realization of an effective school. The findings of this study are in agreement with Marzano (2003) who identified the critical role of providing support for teachers in actualizing an effective school system. Thus, this results have further confirmed the findings of Othman \& Yee (2015) that with the internalization and application of entrepreneurial leadership practice in the day to day running of their schools, principals stand a better chance to improve their school effectiveness and establish a suitable atmosphere that enables effective teaching and learning.

\section{Conclusion}

The results of this study illustrated that there exists a significant and high relationship between entrepreneurial leadership practice and school effectiveness and also, among the dimensions of entrepreneurial leadership, accelerator behavior appeared to have high predictive ability of school effectiveness based on teacher's perception. This simply depicts the imperativeness of entrepreneurial leadership in achieving school effectiveness in the context of this study. The implication is that the findings highlight the need for school principals to employ the elements of entrepreneurial leadership practice and most especially accelerator behavior for the attainment of effectiveness. The ministry of education and policy makers also has a critical role of designing and formulating policies and programs that are aimed at enlightening, training and supporting school principals to apply the elements of entrepreneurship in the daily administration of their schools for the attainment of an affective school system. This research adds to the limited works on entrepreneurial leadership in educational settings based on Nigerian context (Roomi \& Harrison, 2011; Xaba \& Malindi, 2010; Yusof, 2009).

\section{Recommendations}

Based on the findings of the research, the following recommendations are made:

1. Secondary school heads should utilize all components of entrepreneurial leadership in discharge of their duties to promote school effectiveness and encourage creativity/innovation among the teachers.

2. The policy makers in Zamfara State and beyond should take into consideration the utilization of entrepreneurial leadership in policy design, implementation and evaluation towards achieving school effectiveness. 
INTERNATIONAL JOURNAL OF ACADEMIC RESEARCH IN BUSINESS AND SOCIAL SCIENCES Vol. 8, No. 12, Dec, 2018, E-ISSN: 2222-6990 @ 2018 HRMARS

3. This study was limited to sampling the opinion of teachers at the secondary school level only; therefore, future researchers should look into the possibility of including other stakeholders such as principals and parents as respondents.

4. Future research should focus on the perception of teachers at other levels of education, since this research is only limited to the perception of teachers at the secondary level only.

\section{References}

Abd-Elmotaleb, M., \& Saha, S. K. (2013). The role of academic self-efficacy as a mediator variable between perceived academic climate and academic performance. Journal of Education and Learning, 2(3), p117.

Adeyemi, T. (2010). Principals leadership styles and teachers job performance in senior secondary schools in Ondo State, Nigeria. International Journal of Educational Administration and Policy Studies, 2(6), 83-91.

Bagheri, Pihie, Z. A., \& Krauss, S. E. (2013). Entrepreneurial leadership competencies among Malaysian university student entrepreneurial leaders. Asia Pacific Journal of Education, 33(4), 493-508.

Baráth, T. (2015). Learning Organization as a Tool for Better and More Effective Schools. Procedia Manufacturing, 3, 1494-1502.

Berglund, K., \& Holmgren, C. (2006). At the Intersection of Entrepreneurship Education Policy and Practice-On conflicts, tensions and closures. International Journal of Entreprepreneurial Venturing (5)1, 9-27.

Borman, G. D., Hewes, G. M., Overman, L. T., \& Brown, S. (2003). Comprehensive school reform and achievement: A meta-analysis. Review of educational research, 73(2), 125-230.

Cogliser, C. C., \& Brigham, K. H. (2004). The intersection of leadership and entrepreneurship: Mutual lessons to be learned. The Leadership Quarterly, 15(6), 771-799.

Cohen, J. (1988). Statistical power analysis.

Dimovski, V., Penger, S., Peterlin, J., \& Uhan, M. (2013). Entrepreneurial leadership in the Daoist framework. Journal of Enterprising Culture, 21(04), 383-419.

Dobbie, W., \& Fryer Jr, R. G. (2013). Getting beneath the veil of effective schools: Evidence from New York City. American Economic Journal: Applied Economics, 5(4), 28-60.

Domitrovich, C. E., \& Greenberg, M. T. (2000). The study of implementation: Current findings from effective programs that prevent mental disorders in school-aged children. Journal of Educational and Psychological Consultation, 11(2), 193-221.

Eyal, O., \& Kark, R. (2004). How do transformational leaders transform organizations? A study of the relationship between leadership and entrepreneurship. Leadership and Policy in Schools, 3(3), 211-235.

Ghani, M. F. A., Siraj, S., Radzi, N. M., \& Elham, F. (2011). School effectiveness and improvement practices in excellent schools in Malaysia and Brunei. Procedia-Social and Behavioral Sciences, 15, 1705-1712.

Greenberg, D., McKone-Sweet, K., \& Wilson, H. J. (2011) Entrepreneurial Thought and Action: ${ }^{\circledR}$ A Methodology for Developing Entrepreneurial Leaders. Berret Koehler publishers 
INTERNATIONAL JOURNAL OF ACADEMIC RESEARCH IN BUSINESS AND SOCIAL SCIENCES

Vol. 8, No. 12, Dec, 2018, E-ISSN: 2222-6990 @ 2018 HRMARS

Gupta, V., MacMillan, I. C., \& Surie, G. (2004). Entrepreneurial leadership: developing and measuring a cross-cultural construct. Journal of Business Venturing, 19(2), 241-260.

Hamzah, M. S. G., Yusof, B. H., \& Abdullah, S. (2009). Headmaster and entrepreneurship criteria. European Journal of Social Sciences, 11(4), 535-543.

Hargreaves, D. H. (2001). A capital theory of school effectiveness and improvement. British educational research journal, 27(4), 487-503.

Kirk, D. J., \& Jones, T. L. (2004). Effective schools: Dallas, TX: Pearson Education. Retrieved from http://www. pearsonassessments.com/NR/rdonlyres/AE0CB466-32E1-4CDD-8B64-11A 595251F7A/0/EffectiveSchools_Final. pdf (January, 2013).

Leithwood, K., \& Jantzi, D. (2006). Transformational school leadership for large-scale reform: Effects on students, teachers, and their classroom practices. School Effectiveness and School Improvement, 17(2), 201-227.

Lezotte, L. (2001). Revolutionary and evolutionary: The effective schools movement. Okemos, MI: Effective Schools Products, Ltd.

Lezotte, L. W. \& Jacoby, B. C. (1991). Effective Schools Practices That Work.

Lezotte, L. W. \& Snyder, K. M. (2010). What effective schools do: Re-envisioning the correlates: Solution Tree Press.

Lumpe, A. T. (2007). Application of effective schools and teacher quality research to science teacher education. Journal of Science Teacher Education, 18(3), 345-348.

Mortimore, P., Sammons, P., \& Thomas, S. (1994). School effectiveness and value added measures. Assessment in Education, 1(3), 315-332.

Mourshed, M., Chijioke, C., \& Barber, M. (2010). How the world's most improved school systems keep getting better. McKinsey.

Ofoegbu, F., Clark, A., \& Osagie, R. (2013). Leadership Theories and Practice: Charting the Part for Improved Nigerian Schools. Journal of the Commonwealth Council for Educational Administration and Management (CCEAM), 41(2), 67-76.

Olasode, S. A. (2015) Teachers' Perception of Entrepreneurial Leadership Practices of Secondary School Principals in Ondo State, Nigeria. International Journal of Research and Development.

Othman, N., \& Yee, C. S. (2015). Empowering teaching, learning, and supervision through coaching in action research. Journal of Management Research, 7(2), 98.

Pihie, Z. A. L., Asimiran, S., \& Bagheri, A. (2014). Entrepreneurial leadership practices and school innovativeness. South African Journal of Education, 34(1), 1-11.

Rea, S., Pathak, J., Savova, G., Oniki, T. A., Westberg, L., Beebe, C. E., . . Huff, S. M. (2012). Building a robust, scalable and standards-driven infrastructure for secondary use of EHR data: the SHARPn project. Journal of biomedical informatics, 45(4), 763-771.

Roomi, M. A., \& Harrison, P. (2011). Entrepreneurial leadership: What is it and how should it be taught? International Review of Entrepreneurship.

Saleem, Farhat, et al. "Determinants of School Effectiveness: A study at Punjab level." International Journal of Humanities and Social Science 2.14 (2005): 242-251.

Shannon, G. S., \& Bylsma, P. (2007). Nine characteristics of high-performing schools: A research-based resource for schools and districts to assist with improving student learning. Washington Office of Superintendent of Public Instruction. 
Thornberry, N. (2006). Lead like an entrepreneur: McGraw Hill Professional.

Walker, K., \& Carr-Stewart, S. (2006). Beginning principals: Experiences and images of success. International Studies in Educational Administration, 34(3), 17-36.

Waters, T., Marzano, R. J., \& McNulty, B. (2003). Balanced Leadership: What 30 Years of

Research Tells Us about the Effect of Leadership on Student Achievement. A Working Paper.

Woods, P. A., Bennett, N., Harvey, J. A., \& Wise, C. (2004). Variabilities and dualities in distributed leadership findings from a systematic literature review. Educational Management Administration \& Leadership, 32(4), 439-457.

Zins, J. E. (Ed.). (2004). Building academic success on social and emotional learning: What does the research say?. Teachers College Press. 